\title{
Study on the Construction of Urban Ecological Residential Area in Linyi City \\ Zhongxiang Yuan
}

\author{
School of Civil Engineering \& Architecture of Linyi University, Linyi, Shandong, China \\ yuanzhongxiang@lyu.edu.cn
}

Keywords: Ecological residential area; Problem; Suggestions; Linyi City

\begin{abstract}
With the improvement of living standards, citizens gradually require the improvement of residential standards. People Not only intend to enhance the residential environment, at the same time, also pay more attention to ecological and environmental protection. In this paper, it is to study the ecological residential area and many problems in the process of design in Linyi city. As to those matters in the course of city' ecological residential design, government should not only positively make steps to deal with them, but also improve the developers' sense of responsibility, in order to refrain from some matters from the beginning and at the same time starting from the public point, strengthen people's awareness of ecological residence.
\end{abstract}

\section{Introduction}

The construction of urban ecological areas is an important sign of social development and progress, the quality of housing is also increasingly high demand with the continuous improvement of people's income.

The new ecological residential area with natural breath and vitality has become the focus of many people. How to protect the environment and natural resources, make people and nature live in harmony; how to carry out specific issues of different characteristics in different areas, the problems in the construction of ecological residential areas, and how to solve this problem is of great practical significance to explore the construction of ecological residential area.

\section{Overview on the Construction of Urban Ecological Residential Area}

The construction of urban ecological residential area is a harmonious relationship between human and nature, applied economics, biology, sociology and other disciplines of knowledge and various technical means to control the various relationships in the ecological residential areas. reflecting a "ecological" or "sustainable" planning concept, it takes people and nature as a whole, integrated economic, ecological and other elements, coordinate the relationship between environmental protection, economic development, social harmony, promote human living space to a more orderly, healthy development, realize the harmony between man and nature [1].

Urban ecological residential area mode shown in Fig. 1. This model fully reflects the guiding principles of government and life-cycle management, emphasizing the government at the macro level remains closely with appropriate guidance, to maintain ecological residential area of sustainability.

\section{Problems in the Construction of Ecological Residential Areas in Linyi City}

The Misunderstanding of the "Green Development". Ecological residential area inseparable from the "green development", which seeks the harmonious coexistence between man and nature, people close to the green, green has also been affected. But in the "green development" ecological residential area, many real estate developers there are errors, the first green building is equal to grassland construction. Blindly copying foreign land, lawn excessive use, which is in Lan Bay Park, Hengda oasis and Dacheng County are reflected [2]. Developers in order to create a green environment, excessive use of turf, many of which are not the kind of abuses, although ornamental 
great, but people can not participate, and the maintenance costs are very large, so that the green building construction is not equal to the grass appropriate [3].

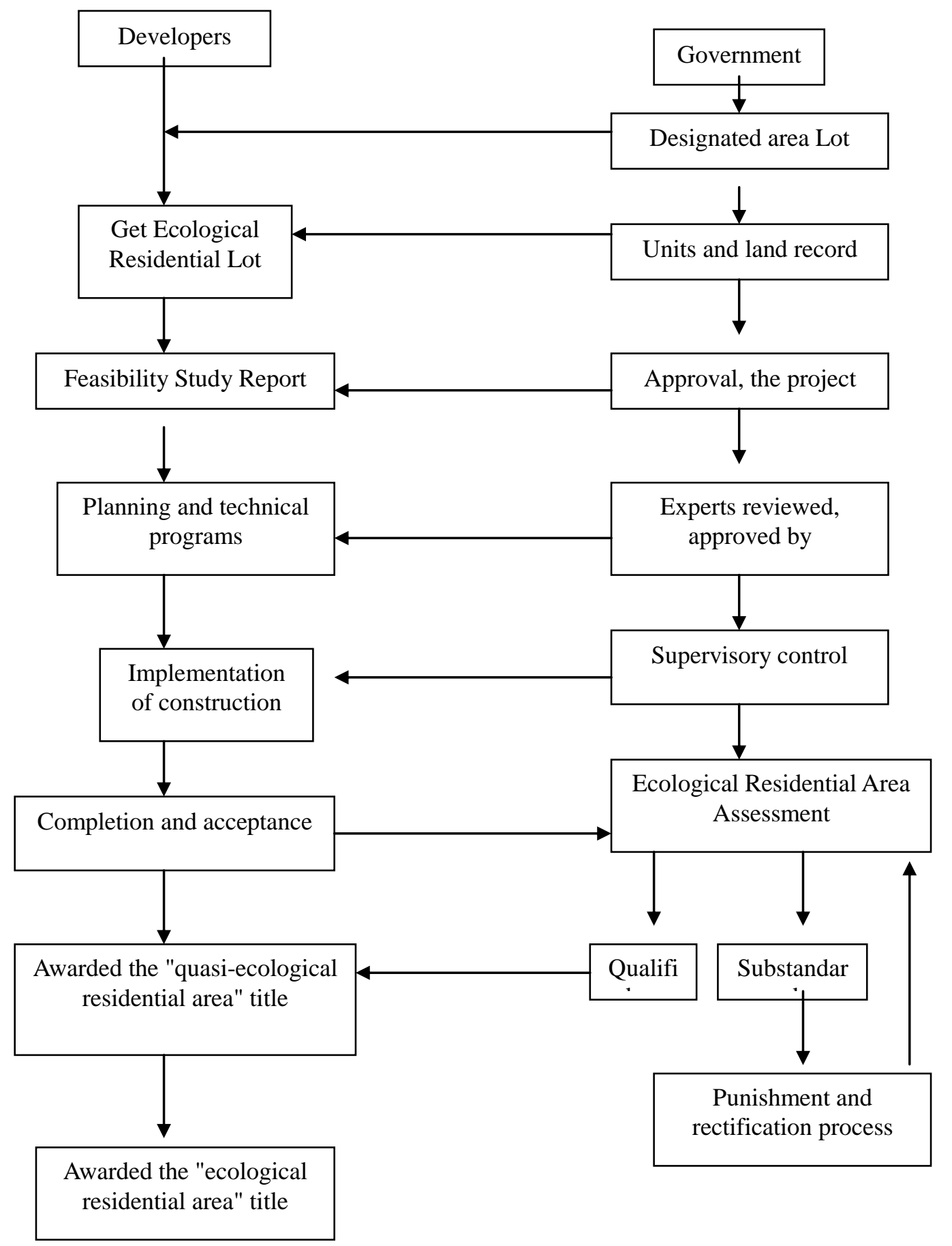

Figure 1. The mode of city ecology resident construction

The second misunderstanding is to select a single species and a single green level. Most green is good for you, but it should be an appropriate choice. In locally grown plants suitable for local growing, not only can save a lot of costs but also can build people's favorite environment. Ecological residential area is not designed to pursue different and fashionable, but a pursuit of harmony between man and nature co-prosperity, "green development" does attract people's attention, but not just more points turf, the introduction of several wonderful plant is green development, we should actively avoid such errors.

Renovated over the Pursuit of Luxury, Material Application Unreasonable. Comfortable 
living the dream of every home buyers, but also cause great waste of energy. In some high-end residential villa development, large windows, central air conditioning, uninterrupted water supply has become the focus of the pursuit of the developer, it also brings a great waste of resources. Like the pursuit of comfortable luxury decoration numerous examples, real estate developers have become almost the same criteria [4]. At the same time, in order to attract the interest of customers to buy, launched the "buy a house decoration" policy when houses. But in the renovation process, does not consider the environmental and health, only the blind pursuit of noble and beautiful [5]. As Hengda oasis in the houses in the launch of the brand renovation, although people feel very comfortable and elegant, all kinds of brand-name to bring people psychological satisfaction and pride, but it ignores the irrational use of decoration materials in the body of injury [2]. Too extravagant, irrational use of materials, apparently set aside the ecological residential area initial design concept, just blind pursuit of modernization, not to ignore the true meaning of ecological living.

Ecological Residential Area Road System Construction Unreasonable. In many cases, ecological residential area contact with the outside world mainly through road transport links, which makes road design in residential area is more important. Combined with the concept of ecological road construction, especially motor vehicle lanes and sidewalks, making it more natural characteristics, showing the natural beauty of the environment. However, in the culmination of ecological construction Fufeng County real estate, only concerned with how much of the road, the pace, how to reach the city or elsewhere in the shortest possible time, without considering how to become more close to nature, how can we truly appreciate nature fresh, how to make arrangements with the city road traffic network integration residential areas, bringing just a fast-paced modern life in a hurry, so that people feel less traffic and integration of natural ecological residential area.

Ecological Residential Area "Rich" Trend. Urban ecological residential area in pursuit of harmony between man and nature, naturally in many aspects of the design, development, and general community vary [6]. For example, in Dacheng county Fu style design, the introduction of rare tree species, although added features, but development costs increased; Hengda oasis on home improvements, using a lot of brand design, resulting in higher costs [2]. Ecological residential area showing a "rich" trend community is obvious, so many people stay away.

\section{Suggestions on Promoting the Construction of Ecological Residential Areas in Linyi City}

The Evaluation of Ecological Housing Needs to Establish a Scientific and Unified Standard. Various real estate developers play the so-called "eco residential area" "green residential" brand development and the western countries compared, there is still a large gap [7]. As in Linyi City Ecological Residential District in the construction of "green development", people of the concept are not fully understood only thought plant some trees, flowers and grass is green development, this is totally unreasonable. For above problems, the government should as soon as possible to develop "ecological residential area" and "ecological residential area" certification system. These problems to promote fair competition in the real estate industry and protect the rights and interests of consumers have a very important significance.

Improve Residents' Understanding of Ecological Residential Area. In fact, many members of the public in the Linyi do not understand the true meaning of "eco residential area" "ecological house" [8]. Understanding of the ecological residential area often just stay within the narrow range of "cell vegetation, water". Many people chose the Hengda oasis, Lan Bo Wan, are directed at their advocacy of ecological concept to, but when asked them what kind of residential area to ecological? They seem very vague, in their view, thought is the ecological environment is good, in fact, this is wrong.

So, as people understand the concept of ecological residential area is not clear, this needs to be guided to their ecological concepts, also the residents' awareness of the ecological environment to lifestyle culture, so that people really understand the true meaning of ecological living. Of course, this also needs to improve the ecological consciousness of the government, thus adaptation policies to guide and encourage, make the human and natural harmony [9]. 
To Promote the Development of Ecological Residential Area to the Public. Due to the ecological residential area can fully reflect the people pursuit of the living quality of the district (health, green, environmental protection, ecological), embody the harmonious development of human settlements. However, eco residential area construction tend to be more careful, sleek, chic, and thus makes the higher construction costs, such ecological residential area popularization also won't get solved thoroughly [10].

Therefore, in the course of the construction of the eco city residential areas, the state should not only give appropriate policy support, embody the "ecological compensation", to improve the developers with enthusiasm. At the same time, as a developer should re positioning of the market, introduced some economic housing, the ecological residential tend to civilians, popular, and not just for the rich and the construction of residential areas, for example, for oasis Hengda Real Estate in the decoration of houses can try to adopt different mode of decoration, in order to adapt to the needs of different consumer groups.

Improve the Ecological Residential Area of the Road System, Advocate Green Travel. For the design of the ecological residential district road, we can not only consider in the area of design, should pay more attention to the harmony and compatibility. For the wind like Fu, Dacheng county road design is not reasonable, we should actively to improve, repair, the ecological residential district in the city traffic and traffic coordination is people not only enjoy the fast traffic convenience, must enjoy the road design combines with the nature of comfort and happiness. Attract people to return to the road on foot. At the weekends down all the troubles, to get close to nature, to the breath of natural breathing.

At the same time, in the road construction should also water supply and drainage system, power system, transmission line combine to form joint channel. Channel joint is special open space, not only can increase the land utilization rate, but also can greatly improve the residential landscape.

\section{Summary}

The construction of the ecological residential district is a comprehensive, various, complicated process. It not only needs the sociologist, designer, government departments and developers and the broad masses of the people involved in, also need to continuous efforts in many ways. Residential area is not only an important part of the city; residential district development is the development of social progress important symbol.

\section{Reference}

[1] Qin Kun. The sustainable development on ecological housing. Shanghai housing information journal, 2010, 20 (10) pp.21-26.

[2] Information on Http://www.linyi58.com/pub/wml.txt/35679-3.html.

[3] Zhang Wei. The planning and design of urban ecological residential district. Heilongjiang science and technology information, 2009, 25 (8) pp.19-20.

[4] Yao Quan. Analysis of quality residential district planning and design. Shanghai science and Technology Park monthly, 2010, 22 (4) pp.15-16.

[5] Sui. On Ecological City Jiaxu and ecological city construction. Beijing: Foreign Trade University China, 2011

[6] Tang Liqiong. Discussion on urban ecological construction. Tibet: University of Tibet, 2012

[7] Ma Dong. Study on planning and design of urban ecological residential area. Publishing House of Beijing Institute of Technology, 2012, pp.41-42.

[8] Gao Lei. Study on landscape planning and design of urban ecological residential area. Kunming: Kunming University of Science and Technology, 2008

[9] Shinano. "Comparison of root growth and nitrogen absorbing ability between Gramineae and Le gum during the vegetative stage”. Soil Sci Plant Nut r , 2004, 16 (11) , pp.22-26.

[10]Varndermeer J. The Ecology of Intercropping. British: Cambridge University, 2010. 